\title{
Glycogen synthase kinase $3 \beta$ in tumorigenesis and oncotherapy (Review)
}

\author{
RUI HE ${ }^{1}$, SUYA DU ${ }^{2}$, TIANTIAN LEI ${ }^{3}$, XIAOFANG XIE $^{4}$ and YI WANG ${ }^{5,6}$ \\ ${ }^{1}$ Department of Union, West China Hospital of Sichuan University, Chengdu, Sichuan 610041; \\ ${ }^{2}$ Department of Clinical Pharmacy, Sichuan Cancer Hospital and Institute, Sichuan Cancer Center, \\ School of Medicine, University of Electronic Science and Technology of China, Chengdu, Sichuan 610041; \\ ${ }^{3}$ Department of Pharmacy, Chongqing Health Center for Women and Children, Chongqing 400013; \\ ${ }^{4}$ Department of Medicine, School of Medicine; ${ }^{5}$ Personalized Drug Therapy Key Laboratory of \\ Sichuan Province, Department of Pharmacy, Sichuan Provincial People's Hospital, School of Medicine, \\ University of Electronic Science and Technology of China, Chengdu, Sichuan 610041; ${ }^{6}$ Center of Translational Medicine, \\ Sichuan Academy of Medical Sciences and Sichuan Provincial People's Hospital, Chengdu, Sichuan 610072, P.R. China
}

Received June 17,2020; Accepted September 17, 2020

DOI: $10.3892 /$ or.2020.7817

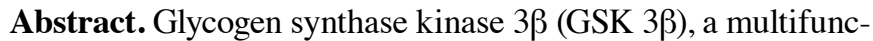
tional serine and threonine kinase, plays a critical role in a variety of cellular activities, including signaling transduction, protein and glycogen metabolism, cell proliferation, cell differentiation, and apoptosis. Therefore, aberrant regulation of GSK $3 \beta$ results in a broad range of human diseases, such as tumors, diabetes, inflammation and neurodegenerative diseases. Accumulating evidence has suggested that GSK $3 \beta$ is correlated with tumorigenesis and progression. However, GSK $3 \beta$ is controversial due to its bifacial roles of tumor suppression and activation. In addition, overexpression of GSK $3 \beta$ is involved in tumor growth, whereas it contributes to the cell sensitivity to chemotherapy. However, the underlying regulatory mechanisms of GSK $3 \beta$ in tumorigenesis remain obscure and require further in-depth investigation. In this review, we comprehensively summarize the roles of GSK $3 \beta$ in tumorigenesis and oncotherapy, and focus on its potentials as an available target in oncotherapy.
\end{abstract}

\section{Contents}

1. Introduction

2. Regulation of GSK $3 \beta$

Correspondence to: Dr Yi Wang, Department of Pharmacy, Personalized Drug Therapy Key Laboratory of Sichuan Province, Center of Translational Medicine, Sichuan Academy of Medical Sciences and Sichuan Provincial People's Hospital, 32 West First Ring Road, Chengdu, Sichuan 610072, P.R. China

E-mail: w_yi@yahoo.com

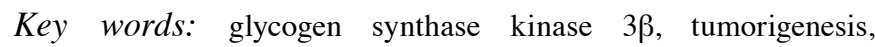
oncotherapy, GSK $3 \beta$ inhibitors
3. Role of GSK $3 \beta$ in tumorigenesis

4. Role of GSK $3 \beta$ in oncotherapy

5. GSK $3 \beta$ inhibitors in antineoplastic treatment

6. GSK $3 \beta$ in cancer immunotherapy

7. Conclusion

\section{Introduction}

Glycogen synthase kinase 3 (GSK3), a member of the mitogen-activated protein (MAP) kinase superfamily, has two highly conserved homologous isoforms, GSK $3 \alpha(51 \mathrm{kDa})$ and GSK $3 \beta(47 \mathrm{kDa})$. Discovered in 1980, both of these two isoforms are multifunctional serine and threonine protein kinases, and they are widely expressed in all eukaryotes (1-3). Encoded by the human chromosome 19q13.2 and 3q13.33, respectively, GSK $3 \alpha$ and GSK $3 \beta$ share $98 \%$ identical sequences in their kinase domains $(4,5)$. Despite structural similarities, their functions are different by phosphorylation at distinctive sites (5). For the activation of GSK $3 \alpha$ and GSK 3 $\beta$, tyrosine 279 (Y279) and tyrosine 216 (Y216) are phosphorylated by upstream signaling molecules respectively, and these two sites are located at the T-loop of GSK 3 (activation domain) (Fig. 1). Notably, GSK $3 \alpha$ and GSK $3 \beta$ are inactivated by site-specific phosphorylation, which is tightly controlled by diverse mechanisms (6). All these mechanisms for the inactivation of GSK $3 \alpha$ at Ser21 and GSK $3 \beta$ at Ser9 have been revealed to be attributed to the phosphoinositide3 kinase (PI3K)-dependent mechanism (7). Activated by PI3 kinase, protein kinase A (PKA), protein kinase B (PKB) (also termed as Akt), protein kinase C (PKC) and p90Rsk contribute to the inactivation of GSK 3 , which ultimately leads to the dephosphorylation of GSK 3 substrates (8). Initially, the inactivation of GSK 3 was considered to be a critical mediator in glycogen metabolism and insulin signaling, since it could give rise to the phosphorylation of glycogen synthase and could promote glycogen synthesis (9). Currently, emerging 
evidence has demonstrated that GSK 3, particularly GSK $3 \beta$, is well-established as a vital component in signaling pathways of cell regulation, involving cell proliferation, differentiation, motility, apoptosis and the cell cycle $(1,2,10)$. As an attractive therapeutic target, GSK 3 has been revealed to be implicated in the pathogenesis of numerous human diseases, such as diabetes, inflammation, Alzheimer's disease, cardiovascular and bipolar disease (11-13). In addition, GSK $3 \beta$ has been demonstrated to be a transcription factor regulating tumor progression, invasion and metastasis $(14,15)$. In different types of cancers, GSK $3 \beta$ plays a controversial role as a tumor suppressor or a tumor promoter $(16,17)$. Furthermore, GSK $3 \beta$ has been demonstrated to be a key regulator of chemo-resistance and radio-resistance in tumor treatment $(18,19)$. Therefore, the regulative roles of GSK $3 \beta$ in tumor development and progression require elucidation. In addition, to date, it has been revealed that GSK $3 \beta$ inhibitors are potential therapeutic drugs in cancer therapy, thus, pre-clinical and clinical studies of GSK $3 \beta$ inhibitors are also presented.

\section{Regulation of GSK $3 \beta$}

It has been revealed that the activity of GSK $3 \beta$ could be regulated in a substrate-specific manner, which comprises four key mechanisms: Phosphorylation, subcellular localization, the formation of protein complexes and the phosphorylation status of GSK $3 \beta$ substrates (12). Among them, phosphorylation is deemed to be the most important regulatory mechanism of GSK $3 \beta$, which would lead to the inactivation of GSK $3 \beta$ at Ser 9 . The activated PI3K/Akt signaling pathway phosphorylates GSK $3 \beta$ at inhibitory serine residues and the phosphorylation may result in the activation of transcription factors in response to carcinogenesis, for instance activating protein-1 (AP-1), cyclic adenosine monophosphate (cAMP)-response element binding protein (CREB), $\beta$-catenin, $\mathrm{c}-\mathrm{Myc}$ and nuclear factor-kappa $(\mathrm{NF}-\kappa \mathrm{B})(1,20)$. In addition, upstream proteins of GSK $3 \beta$, including P70S6 kinase, extracellular signal-regulated kinases (ERKs), p90sk (also called MAPKAP kinase-1), protein kinase $\mathrm{C}(\mathrm{PKC})$ and cAMP-dependent protein kinase [protein kinase A, (PKA)], could lead to the inactivation of GSK $3 \beta(1,21,22)$. Each regulatory kinase is influenced by GSK $3 \beta$ distribution, while scaffolding proteins could restrain the interaction between kinases (6) (Fig. 2A). It has been established that the phosphorylation of tyrosine at 216 site of GSK $3 \beta$ (Tyr216) is regulated by calcium-dependent tyrosine kinase, proline-rich tyrosine kinase 2 (PYK2), cAMP-activated protein tyrosine kinase, Zaphod kinase 1 (ZAK1) or Fyn $(23,24)$. Additionally, phosphorylation of GSK $3 \beta$ at Tyr216 is regulated by mitogen-activated protein kinase (MEK1/2) (25). Generally, GSK $3 \beta$ is classified as an active constituent enzyme in the cytoplasm of resting cells. When activated, GSK $3 \beta$ is accumulated in the nucleus and mitochondria (26) (Fig. 2B). Notably, by activating the genes of downstream transcription factors and recruiting the aggregation of these transcription factors, nuclear translocation of GSK $3 \beta$ regulates a great number of transcription factors (27).

More than 40 proteins are downregulated by GSK $3 \beta$. These proteins are involved in a broad range of cellular processes, including protein synthesis, cell differentiation, proliferation and apoptosis $(2,10,14)$. Substrates that are closely related to tumorigenesis and cancer development tend to be dephosphorylated. In the canonical Wnt signaling pathway, $\beta$-catenin, an important element of Wnt signaling, is controlled by GSK $3 \beta$ (28). With the absence of Wnt signaling, activated GSK $3 \beta$ forms a complex with adenomatous polyposis coli (APC) and the transcriptional co-activator $\beta$-catenin, and therefore the complex binds with the scaffolding protein Axin. This newly formed complex enables GSK $3 \beta$ to phosphorylate $\beta$-catenin and leads to the degradation of $\beta$-catenin. Conversely, the Wnt signaling pathway could inactivate GSK $3 \beta$ and prevent the phosphorylation of $\beta$-catenin by GSK $3 \beta$ (29). In addition, $\beta$-catenin binds to the T-cell factor (TCF)/lymphocyte enhancer factor (LEF), and ultimately promotes the transcription of TCF/LEF transcription factor family-related genes, including proto-oncogenes, such as c-Myc, cyclin D1 and the vascular endothelial growth factor (VEGF), as well as genes that regulate cell invasion and migration, including matrix metalloproteinase-7 (MMP-7) (30-32). Therefore, as the upstream gene of $\beta$-catenin, GSK $3 \beta$ plays a pivotal role in cell proliferation, migration, metastasis and differentiation by controlling Wnt signaling. Additionally, other proto-oncogenic or tumor suppressing transcription factors (such as p53) and translation factors are the substrates of GSK $3 \beta$. With regard to DNA damage studies, the increasingly activated GSK $3 \beta$ in the nucleus and mitochondria promotes the expression of the tumor suppressor protein $\mathrm{p} 53$, and forms a complex with $\mathrm{p} 53$, which enhances the response of p53-induced apoptosis $(33,34)$. Furthermore, GSK $3 \beta$ directly phosphorylates Kruppel-like factor 6 (KLF6), a zinc-finger transcription factor which is a tumor suppressor, inhibiting the tumor growth by increasing KLF6-mediated growth suppression through p53-independent transactivation of p21 (35) (Fig. 3).

\section{Role of GSK $3 \beta$ in tumorigenesis}

For decades, accumulating research has been exploring the role of GSK $3 \beta$ in human oncology. Based on the studies of the GSK $3 \beta$ signaling mechanism, the regulation of GSK $3 \beta$ in cancer progression is intricate $(14,36)$. It has been demonstrated that GSK $3 \beta$ acts as a tumor suppressor in prostate cancer, by inhibiting androgen receptor-mediated cell growth (37). Conversely, it has been observed in colon cancer cell lines and colorectal cancer patients that the expression levels and the enzyme activities of GSK $3 \beta$ were higher than normal cells, therefore GSK $3 \beta$ appears to be a tumor promoter (38). Herein, in order to further elucidate GSK $3 \beta$ as a potential therapeutic target for various cancers, a comprehensive review about the multiple roles of GSK $3 \beta$ in tumorigenesis is provided.

GSK $3 \beta$ as a tumor suppressor. Since GSK $3 \beta$ downregulates numerous proto-oncogenic proteins and cell cycle checkpoint proteins, GSK $3 \beta$ has been generally recognized as a tumor suppressor by inhibiting cell proliferation (39). Previous studies have demonstrated that PI3K inhibitor LY294002 and tumor suppressor phosphatase and tension homolog deleted on chromosome 10 (PTEN) stimulate GSK $3 \beta$-mediated degradation of $\beta$-catenin by inhibiting the PI3K/Akt pathway, thereby inhibiting the progression of prostate tumors $(40,41)$. In addition, GSK $3 \beta$ is phosphorylated and inactivated by the activation of PI3K/Akt pathway, and therefore, inactivated 


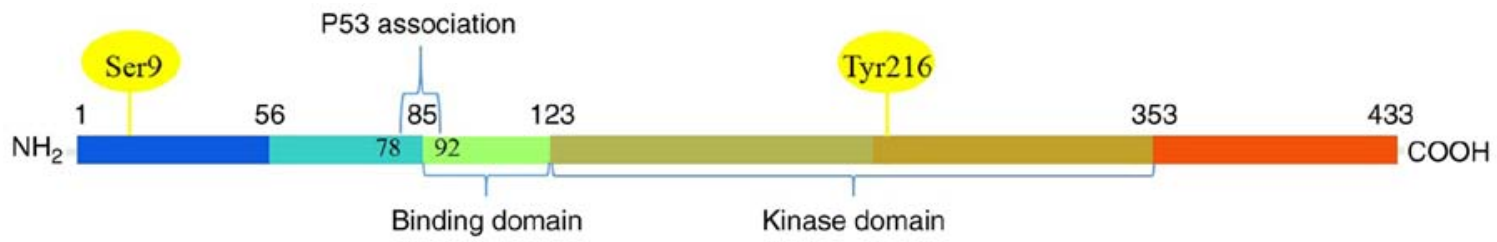

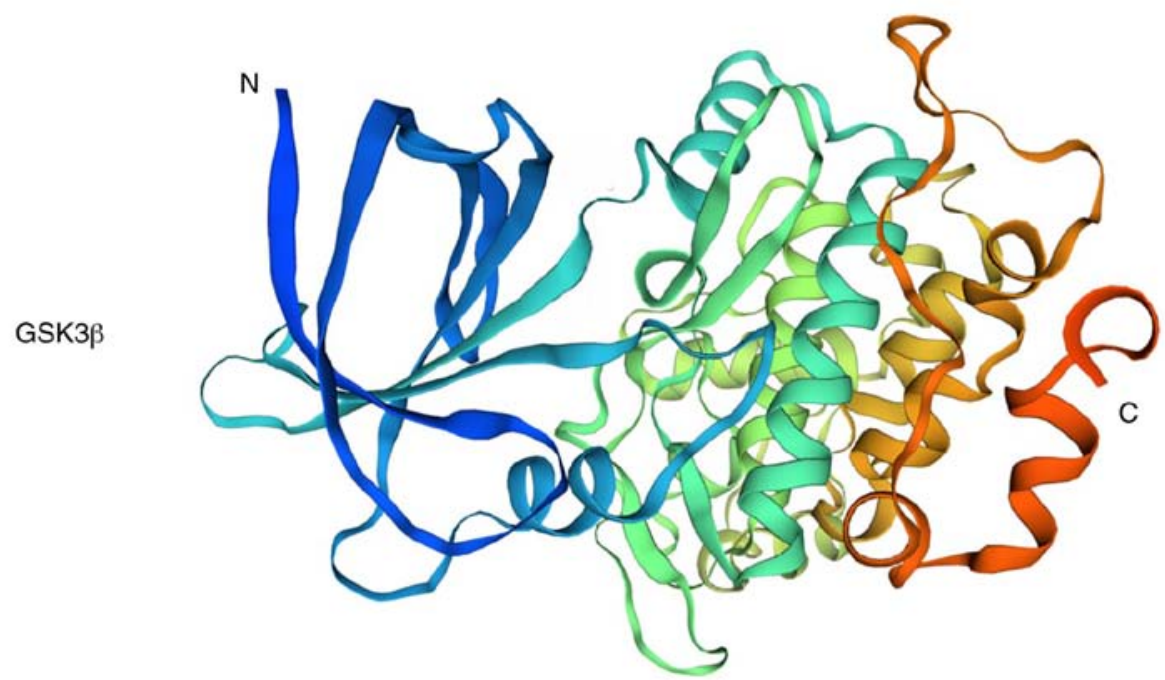

Figure 1. Functional domains and tertiary structures of GSK $3 \beta$ (Homo sapiens). GSK $3 \beta$ is a $47-k$ Da protein consisting of 433 amino-acids in human. The protein contains an $\mathrm{N}$-terminal domain, kinase domain and C-terminal domain. Phosphorylation at Tyrosine (216) in the N-terminal region of GSK $3 \beta$ activates this kinase. Phosphorylation at Serine (9) in the N-terminal region of GSK $3 \beta$ leads to the inactivation of this kinase. The BD includes GSK $3 \beta$ specific binding sites for substrates and protein complexes. GSK $3 \beta$, glycogen synthase kinase $3 \beta ; \mathrm{BD}$, binding domain.

A

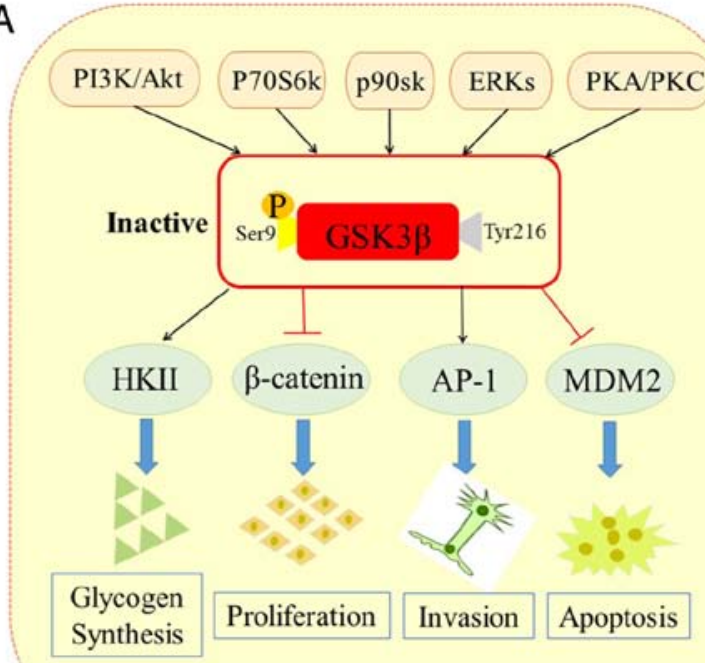

Activated cell

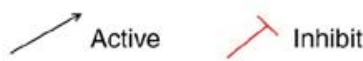

$\mathrm{B}$

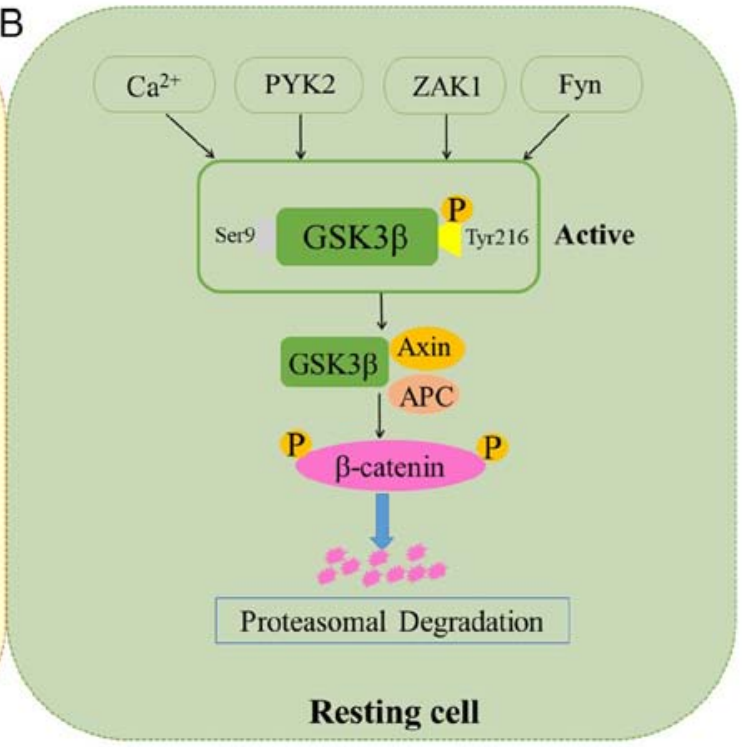

Induce

P Phosphorylation

Figure 2. Regulatory mechanisms of GSK $3 \beta$. The activity of GSK $3 \beta$ can be inactivated by multiple pathways. PI3K/Akt, P70S6K, p90sk, ERKs and PKA/PKC can attenuate GSK $3 \beta$ enzymatic activity by phosphorylating GSK $3 \beta$ at Ser9. Inhibition of GSK $3 \beta$ activity leads to the stabilization and accumulation of $\beta$-catenin in the cytosol. GSK $3 \beta$ inactivation is also involved in glycogen synthesis, protein synthesis, cell proliferation and cell invasion. Additionally, PYK2, $\mathrm{Ca}^{2+}$, ZAK1 and Fyn are able to phosphorylate GSK $3 \beta$ at Tyr216, which increases the GSK $3 \beta$ activity. Subsequently, activated GSK $3 \beta$ phosphorylates downstream target $\beta$-catenin. GSK 3 $\beta$, glycogen synthase kinase3 $\beta$; PI3K, phosphoinositide3 kinase; P70S6K, P70S6 kinase; ERKs, extracellular signal-regulated kinases; PKC, protein kinase C; PKA, protein kinase A; HKII, hexokinase II; AP-1, activating protein-1; MDM2, murine double minute 2; PYK2, proline-rich tyrosine kinase 2; ZAK1, Zaphod kinase 1; APC, adenomatous polyposis coli.

GSK $3 \beta$ prevents the phosphorylation of cyclin D1, inhibits the expression of cyclin D1 gene (CCND1), and accumulates cyclin D1 at the nucleus of breast cancer cells (42). Moreover, it has been revealed that adiponectin could prevent Akt-induced 


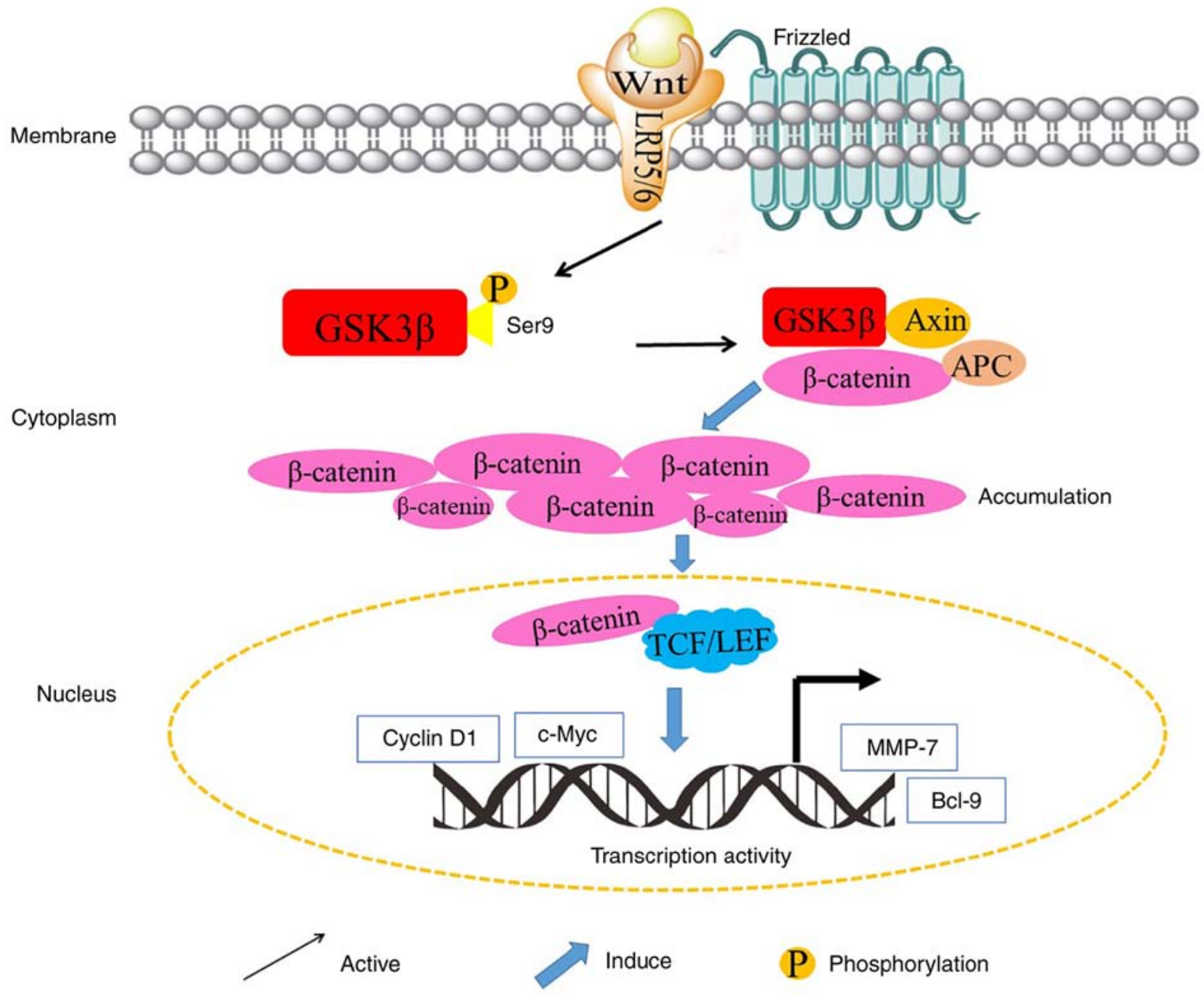

Figure 3. GSK $3 \beta$ regulates the key signaling proteins of the Wnt pathway. In the presence of Wnt, $\beta$-catenin is stabilized and can induce gene transcription. Wnt binds with its co-receptors Frizzled and LRP5/LRP6. Axin and APC interact with phosphorylated GSK $3 \beta$ at Tyr216, which leads to $\beta$-catenin stabilization and cytosol accumulation. Subsequently, $\beta$-catenin is transferred into the nucleus where it activates the transcription of related genes by forming a complex with transcription factors as TCF/LEF. Then, TCF/LEF upregulates the proto-oncogenes (c-Myc and cyclin D1) and cell invasion/migration-related genes (MMP-7 and Cdc37). GSK 3 $\beta$, glycogen synthase kinase 3 $\beta$; APC, adenomatous polyposis coli; TCF, T-cell factor; LEF, lymphocyte enhancer factor; MMP-7, matrix metalloproteinase-7.

phosphorylation of GSK $3 \beta$ and decrease intracellular accumulation and nuclear activity of $\beta$-catenin, subsequently reducing the expression of cyclin D1 (43). This mechanism leads to the apoptosis of breast cancer cells MDA-MB-231 and T47D, and induces the cell cycle arrest of MDA-MB-231 cells at G0-G1 phase. Additionally, it has been revealed by in vivo experiments that the adiponectin-mediated suppressive effect on the GSK $3 \beta / \beta$-catenin signaling pathway could reduce mammary tumorigenesis in female nude mice (43). Therefore, GSK $3 \beta$ is perceived as a tumor suppressor in the tumorigenesis and progression of breast cancer (Fig. 4).

Emerging evidence has revealed that GSK $3 \beta$ phosphorylates various tumor factors (TFs), including cyclin D1, cyclin E, AP-1, c-Jun, p53, p65, Snail, c-Myc and $\beta$-catenin, which would facilitate their degradation and prevent them from entering the nucleus. Thereby, their activities are downregulated in oral squamous cell carcinoma (OSCC) (44-51). It has been indicated that activated GSK $3 \beta$ binds to the mesenchymal Snail gene. Then it inhibits the phosphorylation, degradation and cytoplasmic translocation of Snail, and subsequently inhibits p-cadherin-induced development and homeostasis of epithelial architecture. Consequently, GSK $3 \beta$ may reverse the p-cadherin-contributed oncogenesis in OSCC (52). In addition, it has been demonstrated that the overexpression of focal adhesion kinase (FAK) may activate NF- $\kappa$ B by inactivating GSK $3 \beta$, and therefore promotes cancer cell migration. In addition, the inactivation of GSK $3 \beta$ has also been revealed to suppress cell apoptosis in pre-invasive and invasive OSCC $(51,53,54)$. Furthermore, as the induction of intracellular reactive oxygen species (ROS) stimulates cell apoptosis (55), constitutively activated GSK $3 \beta$ has been reported to increase the mitochondrial membrane potential and to promote ROS $(56,57)$. In addition, several matrix metalloproteinases (MMPs) can also facilitate the migration of cancer cells, thereby upregulating and activating tumor factors, such as Snail, AP-1 and NF- $\mathrm{KB}$ in OSCC $(58,59)$. Collectively, GSK $3 \beta$ could be a potential therapeutic target for the treatment of OSCC by suppressing tumorigenesis (Fig. 4).

It has been indicated that the overexpression of macrophage migration inhibitory factor (MIF) is associated with 


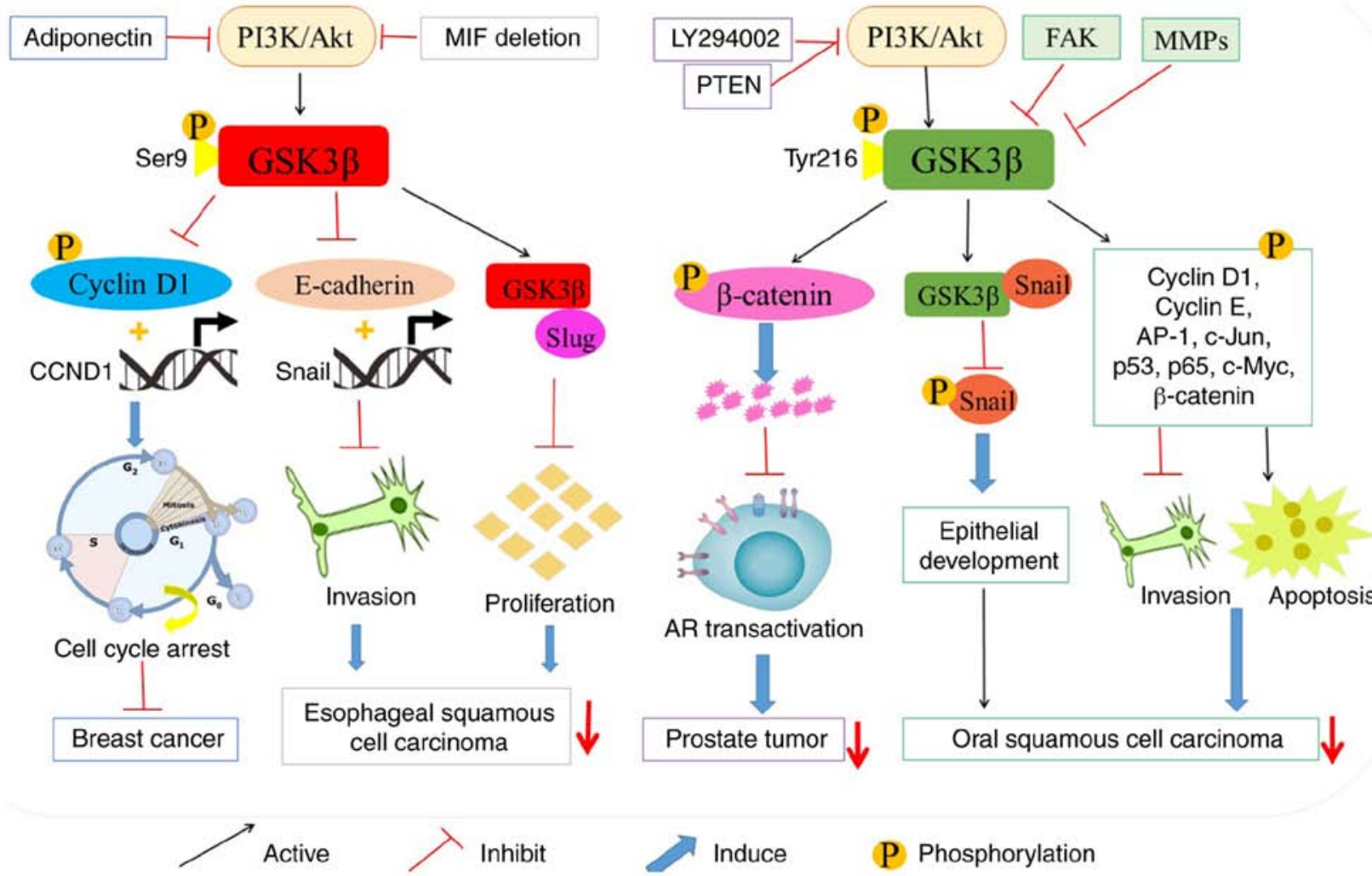

Figure 4. Tumor inhibitory role of GSK 3 $\beta$. LY294002, adiponectin and PTEN suppress GSK $3 \beta$-participated $\beta$-catenin degradation and cell cycle arrest by inhibiting the PI3K/Akt pathway in prostate tumor and breast cancer. The deletion of MIF attenuates Akt-dependent GSK $3 \beta$ phosphorylation and restores tumor suppressor activity of GSK $3 \beta$ in esophageal squamous cell carcinoma. Additionally, GSK $3 \beta$ phosphorylates various tumor factors, facilitates their degradation, and prevents them from entering the nucleus. GSK 3 $\beta$, glycogen synthase kinase 3 $\beta$; PTEN, phosphatase and tension homolog deleted on chromosome 10; AR, androgen receptor; CCND1, cyclin D1 gene; FAK, focal adhesion kinase; MMPs, matrix metalloproteinases; AP-1, activating protein-1.

the development and progression of esophageal squamous cell carcinoma (ESCC) $(60,61)$. Further study has demonstrated that the deletion of MIF attenuates Akt-dependent GSK $3 \beta$ phosphorylation and restores tumor suppressor activity of GSK $3 \beta$ (61). After MIF knockdown, the activation of GSK $3 \beta$ prevents the transcription and expression of Snail gene, one of activators of epithelial-mesenchymal transition (EMT) (62). Moreover, it has also been revealed to inhibit the expression of E-cadherin in ESCC (61). GSK $3 \beta$ not only inhibits cell survival and proliferation, but also restrains tumor invasion and metastasis. GSK $3 \beta$ interacts with Slug, the zinc-finger-containing transcriptional repressor, by suppressing E-cadherin expression and promoting cancer cell migration, invasion and metastasis in the non-small cell lung cancers (NSCLCs) (63). Notably, GSK $3 \beta$ also reduces the stability of Slug protein by promoting the $\mathrm{C}$-terminus of Hsc70-interacting protein (CHIP)-mediated Slug degradation. Conversely, GSK $3 \beta$ inhibitors could induce the accumulation of non-degradable Slug, which increases the migratory and invasive capabilities of lung cancer cells (63). Collectively, the activation of GSK $3 \beta$ may offer a new prospect for inhibiting the tumorigenesis and development of tumors (Fig. 4).

GSK $3 \beta$ as a tumor promoter. GSK $3 \beta$ also plays a critical role in tumor cell proliferation. Overexpression of GSK $3 \beta$ has been observed in various tumor types, including colon, liver, ovarian and pancreatic tumors $(14,64)$. It has been previously reported that GSK $3 \beta$ inhibitors (SB-216763 and AR-A014418) significantly suppress the growth of patient-derived xenograft (PDX) colon cancer, and GSK $3 \beta$ inhibitors are anticipated to be therapeutic agents for colon cancer (64). The overexpression of nuclear GSK $3 \beta$ and the loss of membrane $\beta$-catenin are substantially correlated with poor survival, distant metastasis and worse prognosis of colon cancer patients (65). It is further discovered that the formation of nuclear GSK $3 \beta$ and $\beta$-catenin could decrease the transcription of TCF/LEF target gene (66). In addition, it has been clarified that troglitazone, an agonist of peroxisome proliferator activated receptor $\gamma$ (PPAR $\gamma$ ), could suppress the activity of NF- $\mathrm{KB}$ by inhibiting the activity of GSK $3 \beta$, reducing the expression of G0/G1 phase regulatory proteins including Cdk2, Cdk4 and cyclin B1, and increasing the cleavage of apoptosis-associated proteins, such as caspase- 3 and caspase- 9 of human colon cancer and prostate cancer $(67,68)$. A previous study has revealed that $\mathrm{p} 3^{+/+}$colorectal cancer cells treated with GSK $3 \beta$ inhibitor or GSK $3 \beta$ silencing RNAs could facilitate the increase of p53-dependent apoptosis, instead of cell cycle arrest (69). Furthermore, the activation of PI3K/Akt signaling would result in the inactivation of GSK $3 \beta$, which promotes cell growth by inhibiting apoptosis-related proteins including Bcl-2 family in 1,2-dimethylhydrazine (DMH)-induced colorectal cancer (70).

In addition, the overexpression of GSK $3 \beta$ and the nuclear transcription of NF- $\kappa B$ play critical roles in the survival and proliferation of pancreatic cancer cells (71). However, GSK $3 \beta$ knockdown has been revealed to decrease the expression of 


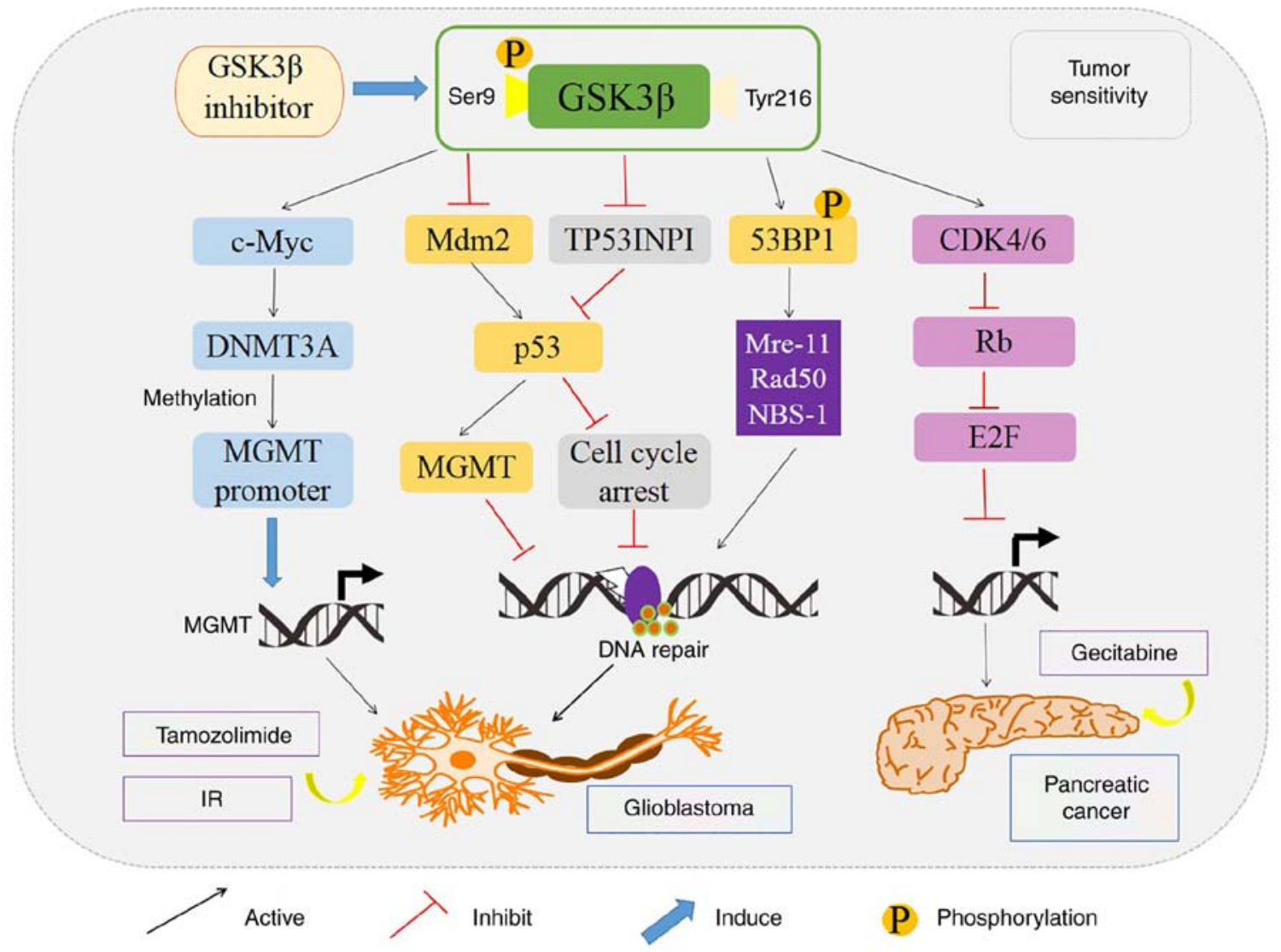

Figure 5. Molecular pathways revealing how GSK $3 \beta$ influences tumor sensitivity to different chemo-therapeutic agents. In glioblastoma, GSK $3 \beta$ inhibition improves temozolomide sensitivity by regulating the Mdm2/P53 and c-Myc/MGMT signaling pathways, which upregulate the methylation of MGMT promoter. Additionally, GSK $3 \beta$ inhibitor enhances the sensitivity of pancreatic cancer to gemcitabine by negatively regulating the cyclin D1/CDK4/6 complex-dependent phosphorylation of Rb tumor suppressor protein. GSK $3 \beta$, glycogen synthase kinase $3 \beta$; DNMT3A, DNA methyltransferase 3 alpha; Mdm2, mouse double minute 2; MGMT, $O^{6}$-methylguanine DNA methyl transferase; TP53INP1, tumor protein 53-induced-nuclear-protein 1; IR, ionizing radiation; 53BP1, p53 binding protein 1; CDK 4/6, cyclin-dependent kinase 4/6; Rb, retinoblastoma; E2F, E2 transcription factor.

Bcl-2 and VEGF, and ultimately result in the growth arrest of tumors (72). In addition, by increasing the expression of cyclin D1 and facilitating the proliferation of ovarian cancer cells, activation of GSK $3 \beta$ could promote the activation of $\mathrm{NF}-\mathrm{\kappa B}$ and lead to cell cycle entering of tumor cells into the $S$ phase (73). Accumulating evidence has revealed that GSK $3 \beta$ could affect intracellular glucose metabolism by restraining the $\mathrm{p53-}$ - NF- $\mathrm{kB}-$ and c-Myc-mediated pathways, and thereafter promote the proliferation and survival of glioblastoma cells and protect them from apoptosis $(20,74)$. Markedly, GSK $3 \beta$ could transfer from the cytoplasm to the nucleus in glioblastoma (GBM) when stimulated by ionizing radiation (IR), and could bind to 553 binding protein 1 (53BP1) at Ser166. The binding of GSK $3 \beta$ with 53BP1 results in the increased DNA double-strand break (DSB) repair in GBM after IR (75) (Fig. 5). Notably, GSK 3 $\beta$ inhibitor, SB216763, comparatively decreases the proliferation of GBM cells and induces apoptosis of GBM cells by halting DSB repair. Similarly, it has been revealed that GSK $3 \beta$ inhibitor could block the NF- $\kappa \mathrm{B}$ pathway and reduce the NF- $\mathrm{kB}$-mediated transcription in osteosarcoma (OSA) (76).

However, as the present inhibitors are not specific but targeting both GSK $3 \alpha$ and GSK $3 \beta$, the oncogenic role of GSK $3 \beta$ has been explored by gain and loss-of-function approaches of transgenic mice, including both knockout and knock-in animal models. A study by Kerkela et al revealed that the GSK $3 \beta^{--}$mice exhibited hypertrophic myopathy, which was caused by cardiomyocyte hyperproliferation with increased expression and nuclear localization of three important regulators of proliferation (GATA4, cyclin D1, and c-Myc) (77). Furthermore, Hoeflich et al reported that disruption of the GSK gene resulted in embryonic lethality caused by severe liver degeneration during mid-gestation with the activation of the transcription factor activation $\mathrm{NF}-\kappa \mathrm{B}$, and the apoptotic sensitivity of GSK $3 \beta^{-/}$fibroblasts was a direct consequence of GSK $3 \beta$ deficiency (78). Using GSK $3 \beta$ knock-in mice, studies have revealed that GSK-3 supports the maintenance of MLL leukemia cells by promoting continuous degradation of the cyclin-dependent kinase inhibitor p27Kip1 $(79,80)$. In addition, phosphorylation of mTOR, p70S6K, and 4E-BP1 were impaired in GSK $3 \beta$ knock-in mice (81). Therefore, GSK $3 \beta$ can be perceived as an oncogenic protein and GSK $3 \beta$ inhibitors are potential new drugs in cancer therapy.

\section{Role of GSK $3 \beta$ in oncotherapy}

GSK $3 \beta$ is also considered to be a pivotal mediator in regulating the sensitivity of tumor cells for chemotherapy and radiotherapy. It has been observed that the expression of GSK $3 \beta$ is significantly increased in paclitaxel-resistant ovarian 
carcinoma cell line (SKOV3) (82). Moreover, downregulation of GSK $3 \beta$ increased the therapeutic effect of 5-fluorouracil (5-FU), abolished cell viability and colony growth, and reduced the xenograft tumor mass in various drug-resistant p53-null colon cancer cell lines, which implies that GSK $3 \beta$ inhibitor, in combination with chemotherapy, may represent a novel strategy for the treatment of chemotherapy-resistant tumors (83). GSK $3 \beta$ inhibition was revealed to allow chemo-resistant carcinoma cells to become more susceptible to the synthetic multi-kinase inhibitor (sorafenib) which inhibits cell growth and angiogenesis (84). In addition, the increased expression of GSK $3 \beta$ phosphorylation at Ser9 has been revealed to promote the chemo-sensitivity in cisplatin-resistant CP70 cells. The pGSK $3 \beta$ (Ser9) increased the cisplatin resistance of ovarian carcinomas by reducing the GSK $3 \beta$ regulated stabilization of p53 expression (85). Furthermore, LY294002, a PI3K inhibitor, has been revealed to enhance chemotherapy-induced apoptosis and the cleavage of caspase- 8 by promoting GSK $3 \beta$ dephosphorylation at Ser9 (86). Similarly, in MCF-7 breast cancer cells, selective inhibition of GSK $3 \beta$ attenuated cytotoxicity induced by histone deacetylase inhibitor trichostatin A (87). Additionally, GSK $3 \beta$ inhibition also enhanced the sensitivity of glioblastoma cells to radiation (75). In glioblastoma, GSK $3 \beta$ inhibition improved the therapeutic effect of temozolomide by modulating the expression of $O^{6}$-methylguanine DNA methyl transferase (MGMT) promoter via c-Myc signaling pathway $(74,88)$. Moreover, GSK $3 \beta$ inhibitor enhanced the sensitivity of pancreatic cancer to gemcitabine by decreasing the expression of tumor protein 53-induced-nuclear-protein 1 (TP53INP1), a pro-apoptotic stress-induced or DSB repair-mediated p53 target gene, and by downregulating the CDK4/6 complex-dependent phosphorylation of $\mathrm{Rb}$ tumor suppressor protein $(89,90)$ (Fig. 5).

Collectively, GSK $3 \beta$ regulates various responses to chemotherapy among a variety of tumor cell types, which is not entirely consistent with its role as a tumor suppressor or tumor promoter. On the one hand, GSK $3 \beta$ inhibitor acts as a tumor promoter to attenuate the sensitivity of breast cancer cells to chemotherapy. On the other hand, GSK $3 \beta$ functions as a tumor promoter for pancreatic cancer and GSK $3 \beta$ inhibitor enhances the sensitivity of pancreatic cancer cells to chemotherapy. Therefore, the mechanisms of the GSK $3 \beta$ signaling pathway in tumorigenesis and drug responses are significantly diverse, and require further investigations.

\section{GSK $3 \beta$ inhibitors in antineoplastic treatment}

GSK $3 \beta$ has been revealed to play a critical role in the regulation of a variety of cellular functions, including cell proliferation, differentiation, motility, apoptosis and the cell cycle $(1,2,10)$. In addition, GSK 3 inhibitors may be appropriate for the treatment of certain diseases, including diabetes, bipolar disorder, inflammation and certain types of cancer (91). Inhibitors of GSK $3 \beta$ are categorized as GSK $3 \beta$-selective or non-selective and ATP-competitive or non-ATP-competitive (92-121).

Lithium, a well-documented inhibitor of GSK3, can promote phosphorylation of GSK $3 \beta$ at Ser9 and inhibit the activity of GSK $3 \beta$ by competing with magnesium $\left(\mathrm{Mg}^{2+}\right)$ rather than ATP or its substrate. It has been indicated that lithium has become a gold standard for the treatment of bipolar mood and nervous disorders $(92,93)$. Additionally, lithium has an effect on embryonic development by promoting the differentiation of epithelial cells, increasi calcngium $\left(\mathrm{Ca}^{2+}\right)$ storage in the bones, and hindering the entering of the cell cycle (94-96). Lithium has been revealed to induce apoptosis in both Jurkat cells and differentiated immortalized hippocampal neurons by stimulating the death domain-containing receptor Fas (97). Notably, the treatment with lithium was revealed to increase the levels of $\mathrm{p} 21^{\mathrm{WAF} / \mathrm{Cipl}}$ (a protein with anti-apoptotic function) and survivin (a protein that supports the growth of cells by suppressing apoptosis and promoting cell proliferation) in human GBM cells (98). Furthermore, lithium was revealed to inhibit cell motility and compromise the invasive phenotype of $\mathrm{v}$-Src-transformed cells, which was mediated by the activation of phospho-tyrosine phosphatases via the regulation of the cell redox status (99).

To date, several compounds targeting GSK 3 are still under pre-clinical studies, and few of them are in clinical trials (Table I). The mechanisms of GSK3 inhibition greatly vary. Both lithium and SB216763 have been demonstrated to have effects on tumor growth by inhibiting cell proliferation, however 9-ING-41 tends to induce apoptosis (100). SB216763, an ATP-competitive inhibitor of GSK $3 \beta$, has been revealed to downregulate AR-mediated prostate cancer cell growth in vitro and in vivo $(101,102)$. It has also been revealed to potentiate the death ligand-induced apoptotic response in pancreatic cancer cells (PANC1 and MIA PaCa-2) by activating the c-Jun N-terminal kinase (JNK) pathway (103). Similarly, SB-415286, another ATP-competitive inhibitor specific for GSK $3 \beta$, was demonstrated to induce the expression of a $\beta$-catenin-LEF/TCF regulated reporter gene (104). Its treatment potentiated TRAIL- and CH-11-induced apoptosis in HepG2 cells, and induced growth arrest and apoptosis in multiple myeloma (MM) cells $(105,106)$. Additionally, it decreased the viability of Neuro-2A cells, and induced G2/M arrest (107). Non-ATP competitive GSK $3 \beta$ inhibitors, including LiCl, TDZD-8 and L803-mts, could also induce significant inhibition of tumor growth (108). A previous study has revealed that TWS119 could reverse the effects of tamoxifen on $\beta$-catenin and Snail expression thereby inhibiting GSK-3 $\beta / \beta$-catenin activation (109). Furthermore, TWS119 exhibited different effects on $\mathrm{CD}^{+}$and $\mathrm{CD} 8^{+} \mathrm{T}$ cells in tumor-infiltrating lymphocytes (TILs) by stimulating the expansion of naive T cell and CD8 stem cell-like memory $\mathrm{T}$ cells, and inducing $\mathrm{CD} 8^{+}$effector T-cell proliferation in TILs (110). The selective GSK $3 \beta$ inhibitor, manzamine A, can reduce the metastatic potential of AsPC-1 pancreatic cancer cells and promote TRAIL-induced cell apoptosis (111). Inhibition of GSK $3 \beta$ with AR-A014418 was also revealed to increase the sensitivity of PANC1 cells to gemcitabine by regulating the $\mathrm{Rb} / \mathrm{E} 2 \mathrm{~F}$ pathway (93) (112).

Notably, 9-ING-41 [benzofuran-3-yl-(indol-3-yl) maleimide], a maleimide-based ATP-competitive small molecule GSK-3 $\beta$ inhibitor, has been demonstrated to be more selective for GSK $3 \beta$ than for other related kinases (113). In vitro cell line studies and in vivo animal models have revealed the antitumor effects of 9-ING-41 in various cancers, including bladder cancer (114), renal cancer (115), neuroblastoma (116), B-cell lymphoma (117), breast cancer (118) and glioblastoma (119). A previous study on 9-ING-41 revealed 
Table I. Specific and non-specific GSK $3 \beta$ inhibitors.

\begin{tabular}{|c|c|c|c|c|}
\hline Compound & Specificity & Inhibition mode & Applications/mechanisms & (Refs.) \\
\hline Lithium & Non-specific GSK $3 \beta$ & $\mathrm{Mg}^{2+}$ competitive & Bipolar mood and nervous disorders & (96) \\
\hline SB216763 & Non-specific GSK $3 \beta$ & ATP competitive & Inhibits AR-dependent reporter gene activity & $(96-99)$ \\
\hline SB415286 & Non-specific GSK $3 \beta$ & ATP competitive & $\begin{array}{l}\text { Induces the accumulation of cells in the } \mathrm{G} 2 / \mathrm{M} \\
\text { phase of the cell cycle and apoptosis in } \\
\text { Neuro- } 2 \text { A cells }\end{array}$ & $(100-103)$ \\
\hline TDZD-8 & Specific GSK3 $\beta$ & Non-ATP competitive & $\begin{array}{l}\text { Activates the ERK pathway and increases } \\
\text { expression of EGR-1 and p } 21 \text { genes, which } \\
\text { suppresses the proliferation of glioblastoma cells }\end{array}$ & (104) \\
\hline L803-mts & Specific GSK3 $\beta$ & Non-ATP competitive & $\begin{array}{l}\text { Significant inhibition of tumor growth in mouse } \\
\text { xeno graft models of prostate cancer }\end{array}$ & $(104)$ \\
\hline TWS119 & Specific GSK3 $\beta$ & ATP competitive & $\begin{array}{l}\text { Decreases ATP production in cells, resulting in } \\
\text { the increase in the AMP/ATP ratio and triggers } \\
\text { AMPK in prostate cancer cells }\end{array}$ & (105 and 106) \\
\hline Manzamine A & Specific GSK3 $\beta$ & Non-ATP-competitive & Inhibits autophagy and tumor growth & (107) \\
\hline AR-A014418 & Specific GSK3 $\beta$ & ATP competitive & $\begin{array}{l}\text { Mainly suppresses the growth of pancreatic } \\
\text { cancer by reducing the phosphorylation of } \\
\text { GSK3 } \alpha \text { with concomitant Notch1 reduction }\end{array}$ & (86 and 108) \\
\hline 9-ING-41 & Specific GSK3 $\beta$ & ATP-competitive & $\begin{array}{l}\text { Inhibits the growth of various cancers and } \\
\text { attenuates the progression of pulmonary fibrosis }\end{array}$ & $(109-117)$ \\
\hline
\end{tabular}

GSK 3, glycogen synthase kinase 3; AR, androgen receptor; ERK, extracellular signal-regulated kinase; EGR-1, early growth response-1; AMP, adenosine monophosphate; ATP, adenosine triphosphate; AMPK, AMP-activated protein kinase.

that it upregulates the phosphorylation of the inhibitory serine residue of GSK $3 \beta$ in ovarian cancer cells, and subsequently induces the apoptosis of ovarian cancer cells (120). A study from Ugolkov et al demonstrated that 9-ING-41 leads to the regression of patient-derived xenograft (PDX) tumors from metastatic pleural effusions obtained from patients with progressive, chemo-refractory breast cancer (118). Their group also revealed that 9-ING-41 significantly enhanced 1-(2-chloroethyl)-3-cyclohexyl-1-nitrosourea (CCNU) antitumor activity in chemo-resistant PDX models of GBM by decreasing tumor size and increasing overall survival (119). In addition, 9-ING-41 could attenuate the progression of pulmonary fibrosis by improving lung functions and inhibition of myofibroblast differentiation in lung fibroblasts ex vivo and pulmonary fibrosis in vivo (121). With significant pre-clinical antitumor activity, 9-ING-41 is under phase $1 / 2$ clinical trials in patients with refractory hematologic malignancies or solid Tumors (Clinical Trials ID: NCT03678883) (https://clinicaltrials.gov/ct2/show/NCT03678883).

\section{GSK $3 \beta$ in cancer immunotherapy}

A previous study has revealed the immune-regulatory role of GSK $3 \beta$ via the phosphorylation of two important transcription factors, NF- $\kappa \mathrm{B}$ and CREB (122). Moreover, the phosphorylation of these two transcription factors could result in proteasomal degradation. In addition, the inactivation of GSK $3 \beta$ has been revealed to lead to the nuclear transfer of $\mathrm{NF}-\kappa \mathrm{B}$ and CREB, which stimulate the secretion of inflammation-related cytokines $(123,124)$.
For the innate immune system, the NK lymphocyte plays a critical role, and its activation relies on specific receptors including NKG2D/2B4 or NKG2D/DNAM-1. However, these activators may inhibit the activity of GSK $3 \beta$ via the ERK or Akt signaling pathways $(125,126)$. Studies on GSK $3 \beta$ knockdown and its inhibitors revealed that the inactivation or silencing of GSK $3 \beta$ leads to NK cell activation and enhanced function $(127,128)$. A study on MM cells indicated that the inhibition of GSK3 upregulated MICA transcription and translation both in MM cell lines and in tumor cells isolated from MM patients, without significant effects on the basal expression of the MICB and DNAM-1 ligand poliovirus receptor/CD155. Moreover, GSK 3 inhibitors increased NK-mediated cytotoxicity of MM cells by activating NK cell degranulation. In addition, combined with lenalidomide or melphalan, treatment with GSK-3 inhibitors induced MICA expression and increased NK cell-mediated tumor killing by promoting NKG2D recognition in NK cells. Therefore, GSK-3 inhibitors could be novel therapeutic drugs targeting MICA expression and improving immune response in MM patients (129). For the acute myelogenous leukemia (AML) patients, NK cells expressed high levels of GSK $3 \beta$. Therefore, treatment with the GSK 3 inhibitors or the genetic inactivation of the GSK 3 led to the increased activity of NK cells to kill AML cells. Furthermore, GSK3 inhibition promoted the formation AML-NK cell conjugates by upregulating LFA expression on NK cells and by inducing ICAM-1 expression on AML cells (130). Another study on GSK 3 revealed that its inhibitor significantly upregulated transcription factors associated with late-stage NK-cell maturation, such as E-box binding 
homeobox 2 (ZEB2), PR/SET domain 1 (PRDM1), and T-box 21 (TBX21) and subsequently increased CD57 acquisition and maturation. In addition, NK cells, which were expanded ex vivo in the presence of GSK3 inhibitor, produced more TNF and IFN- $\gamma$, natural cytotoxicity and antibody-dependent cellular cytotoxicity (131). Therefore, currently, there are several ongoing clinical trials of adaptive NK cells treated with GSK 3 inhibitors for relapsed AML, ovarian cancer as well as other solid tumors.

Accumulating evidence has demonstrated the significance of GSK 3 in T cells. Because it is constitutively active in resting $\mathrm{T}$ cells, GSK 3 acts as a negative regulator of T-cell response by inhibiting $\mathrm{CD}^{+} \mathrm{T}$-cell proliferation and IL-2 production (132). The inactivation of GSK 3 can specifically downregulate PD-1 expression by enhancing CD8 ${ }^{+}$CTL function and clearance of lymphoma cells $(133,134)$. Additionally, GSK-3 inhibition was revealed to be as effective as anti-PD-1 and PD-L1 blocking antibodies in suppressing the growth of melanoma and lymphoma in mouse models (135). Therefore, GSK-3 was revealed as a central regulator of PD-1 expression. Recently, the same group revealed that GSK-3 also negatively regulated lymphocyte activation gene-3 (LAG-3) expression on $\mathrm{CD}^{+}{ }^{+}$and $\mathrm{CD}^{+} \mathrm{T}$ cells. The combination of GSK-3 inhibitor with LAG-3 blockade resulted in the suppression of B16 melanoma growth and enhancement of tumor clearance, by increasing the expression of the transcription factor T-bet and binding with the LAG-3 promoter, and subsequently increasing granzyme B and interferon- $\gamma 1$ expression (136). GSK $3 \beta$ inhibition has been reported to increase the tumor cell cytotoxic capacity of $\mathrm{CD} 8^{+}$memory stem $\mathrm{T}$ cells in vitro against gastric cancer cells (137). Moreover, the inactivation of GSK $3 \beta$ has been revealed to stimulate iTreg differentiation and increase the suppressive activity via the activation of the TGF- $\beta /$ Smad 3 signaling pathway (138). Furthermore, treatment of GBM-specific IL-13 CAR-T cells with the GSK 3 inhibitor resulted in reduced PD-1 expression, increased T cell survival and proliferation. Therefore, GSK 3 inactivation has also been revealed to contribute to the tumor treatment in CAR-T cell immunotherapy (139). Because the polarized-M2 phenotype of macrophages affects tumor growth, invasiveness, angiogenesis (140), and GSK $3 \beta$ has been reported to enhance the polarization of microglia toward M2 (141), GSK $3 \beta$ may be the potential therapeutic target for cancer immunotherapy. Collectively, these studies revealed that GSK 3 inhibition could be a new immunotherapeutic strategy for oncotherapy.

\section{Conclusion}

It has been widely acknowledged that GSK $3 \beta$ is involved in tumorigenesis, cancer progression and metastasis. However, there are still controversies about the role of GSK $3 \beta$ as a tumor suppressor or tumor promoter. GSK $3 \beta$ may function as a tumor suppressor which inhibits neoplastic growth in prostate, oral and lung cancer when overexpressed or activated (51,142-144). Conversely, GSK $3 \beta$ has also been revealed to facilitate carcinogenesis, and is recognized as a 'tumor promoter' in colon, pancreatic and ovarian cancers $(65,89,90,120,145)$. Therefore, based on its pivotal role in tumorigenesis and tumor progression, GSK $3 \beta$ is predicted to be a clinical prognostic indicator for certain malignant cancers. In conclusion, a more comprehensive understanding of GSK $3 \beta$ would be comparatively beneficial to disease therapy. Targeting GSK $3 \beta$ may be an ideal therapeutic strategy for malignant tumors that are characterized by infinite proliferation, metastasis and chemo-resistance, thus providing significant insight for the further research of tumor treatment.

\section{Acknowledgements}

Not applicable.

\section{Funding}

The present study was supported by the National Natural Science Foundation of China (grant no. 81802504), the National Key Research and Development Program of China (grant no. 2020YFC2005500), the Key Research and Development Program of Science and Technology of the Department of Sichuan Province (grant no. 2019YFS0514) and the Sichuan Medical Association (grant no. Q19037).

\section{Availability of data and materials}

Data sharing is not applicable to this article, as no datasets were generated or analyzed during the present study.

\section{Authors' contributions}

YW conceived and designed the review. $\mathrm{RH}$ and SD wrote the paper. TL and XX prepared the figures and table. YW reviewed and edited the manuscript. All authors read and approved the manuscript, and agree to be accountable for all aspects of the research in ensuring that the accuracy or integrity of any part of the work are appropriately investigated and resolved.

\section{Ethics approval and consent to participate}

This review does not contain any studies with human participants or animals performed by any of the authors.

\section{Patient consent for publication}

Not applicable.

\section{Competing interests}

The authors declare that they have no competing interests.

\section{References}

1. Grimes CA and Jope RS: The multifaceted roles of glycogen synthase kinase 3beta in cellular signaling. Prog Neurobiol 65: 391-426, 2001.

2. Doble BW and Woodgett JR: GSK-3: Tricks of the trade for a multi-tasking kinase. J Cell Sci 116: 1175-1186, 2003.

3. Embi N, Rylatt DB and Cohen P: Glycogen synthase kinase-3 from rabbit skeletal muscle. Separation from cyclic-AMP-dependent protein kinase and phosphorylase kinase. Eur J Biochem 107: 519-527, 1980.

4. Woodgett JR: Molecular cloning and expression of glycogen synthase kinase-3/factor A. EMBO J 9: 2431-2438, 1990.

5. Thotala DK and Yazlovitskaya EM: GSK3B (glycogen synthase kinase 3 beta). Atlas Genet Cytogenet Oncol Haematol 15: 7-10, 2011. 
6. Jope RS and Johnson GV: The glamour and gloom of glycogen synthase kinase-3. Trends Biochem Sci 29: 95-102, 2004.

7. Fang X, Yu SX, Lu Y, Bast RC Jr, Woodgett JR and Mills GB: Phosphorylation and inactivation of glycogen synthase kinase 3 by protein kinase A. Proc Natl Acad Sci USA 97: 11960-11965, 2000

8. Cross DA, Alessi DR, Cohen P, Andjelkovich M and Hemmings BA: Inhibition of glycogen synthase kinase- 3 by insulin mediated by protein kinase B. Nature 378: 785-789, 1995 .

9. Summers SA, Kao AW, Kohn AD, Backus GS, Roth RA, Pessin JE and Birnbaum MJ: The role of glycogen synthase kinase 3beta in insulin-stimulated glucose metabolism. J Biol Chem 274: 17934-17940, 1999.

10. Jacobs KM, Bhave SR, Ferraro DJ, Jaboin JJ, Hallahan DE and Thotala D: GSK-3 $\beta$ : A bifunctional role in cell death pathways. Int J Cell Biol 2012: 930710, 2012

11. Amar S, Belmaker RH and Agam G: The possible involvement of glycogen synthase kinase-3 (GSK-3) in diabetes, cancer and central nervous system diseases. Curr Pharm Des 17: 2264-2277, 2011.

12. Jope RS, Yuskaitis CJ and Beurel E: Glycogen synthase kinase-3 (GSK3): Inflammation, diseases, and therapeutics. Neurochem Res 32: 577-595, 2007.

13. Luo J: The role of GSK3beta in the development of the central nervous system. Front Biol (Beijing) 7: 212-220, 2012.

14. Luo J: Glycogen synthase kinase 3beta (GSK3beta) in tumorigenesis and cancer chemotherapy. Cancer Lett 273: 194-200, 2009.

15. Chiara F and Rasola A: GSK-3 and mitochondria in cancer cells. Front Oncol 3: 16, 2013.

16. Naito S, Bilim V, Yuuki K, Ugolkov A, Motoyama T, Nagaoka A, Kato T and Tomita Y: Glycogen synthase kinase-3beta: A prognostic marker and a potential therapeutic target in human bladder cancer. Clin Cancer Res 16: 5124-5132, 2010.

17. Tang QL, Xie XB, Wang J, Chen Q, Han AJ, Zou CY, Yin JQ, Liu DW, Liang Y, Zhao ZQ, et al: Glycogen synthase kinase-3ß, $\mathrm{NF}-\kappa \mathrm{B}$ signaling, and tumorigenesis of human osteosarcoma. J Natl Cancer Inst 104: 749-763, 2012.

18. Majewska E and Szeliga M: AKT/GSK3 $\beta$ signaling in glioblastoma. Neurochem Res 42: 918-924, 2017.

19. Domoto T, Pyko IV, Furuta T, Miyashita K, Uehara M, Shimasaki T, Nakada M and Minamoto T: Glycogen synthase kinase- $3 \beta$ is a pivotal mediator of cancer invasion and resistance to therapy. Cancer Sci 107: 1363-1372, 2016.

20. Kotliarova S, Pastorino S, Kovell LC, Kotliarov Y, Song H, Zhang W, Bailey R, Maric D, Zenklusen JC, Lee J and Fine HA Glycogen synthase kinase-3 inhibition induces glioma cell death through c-MYC, nuclear factor-kappaB, and glucose regulation. Cancer Res 68: 6643-6651, 2008.

21. Najib S and Sánchez-Margalet V: Homocysteine thiolactone inhibits insulin-stimulated DNA and protein synthesis: Possible role of mitogen-activated protein kinase (MAPK), glycogen synthase kinase-3 (GSK-3) and p70 S6K phosphorylation. J Mol Endocrinol 34: 119-126, 2005.

22. Eldar-Finkelman H, Seger R, Vandenheede JR and Krebs EG Inactivation of glycogen synthase kinase- 3 by epidermal growth factor is mediated by mitogen-activated protein kinase/p90 ribosomal protein S6 kinase signaling pathway in NIH/3T3 cells. J Biol Chem 270: 987-990, 1995.

23. Hartigan JA, Xiong WC and Johnson GV: Glycogen synthase kinase 3 beta is tyrosine phosphorylated by PYK2. Biochem Biophys Res Commun 284: 485-489, 2001

24. Hartigan JA and Johnson GV: Transient increases in intracellular calcium result in prolonged site-selective increases in Tau phosphorylation through a glycogen synthase kinase 3beta-dependent pathway. J Biol Chem 274: 21395-21401, 1999.

25. Takahashi-Yanaga F, Shiraishi F, Hirata M, Miwa Y, Morimoto S and Sasaguri T: Glycogen synthase kinase-3beta is tyrosine-phosphorylated by MEK1 in human skin fibroblasts. Biochem Biophys Res Commun 316: 411-415, 2004.

26. Bijur GN and Jope RS: Glycogen synthase kinase-3 beta is highly activated in nuclei and mitochondria. Neuroreport 14: 2415-2419, 2003.

27. Diehl JA, Cheng M, Roussel MF and Sherr CJ: Glycogen synthase kinase-3beta regulates cyclin D1 proteolysis and subcellular localization. Genes Dev 12: 3499-3511, 1998.

28. Manoukian AS and Woodgett JR: Role of glycogen synthase kinase- 3 in cancer: Regulation by Wnts and other signaling pathways. Adv Cancer Res 84: 203-229, 2002.

29. Valvezan AJ, Zhang F, Diehl JA and Klein PS: Adenomatous polyposis coli (APC) regulates multiple signaling pathways by enhancing glycogen synthase kinase-3 (GSK-3) activity. J Biol Chem 287: 3823-3832, 2012
30. Peifer $\mathrm{M}$ and Polakis P: Wnt signaling in oncogenesis and embryogenesis-a look outside the nucleus. Science 287: 1606-1609, 2000

31. Lustig B and Behrens J: The Wnt signaling pathway and its role in tumor development. J Cancer Res Clin Oncol 129: 199-221, 2003.

32. Giles RH, van Es JH and Clevers H: Caught up in a Wnt storm: Wnt signaling in cancer. Biochim Biophys Acta 1653: 1-24, 2003.

33. Watcharasit P, Bijur GN, Zmijewski JW, Song L, Zmijewska A, Chen X, Johnson GV and Jope RS: Direct, activating interaction between glycogen synthase kinase-3beta and p53 after DNA damage. Proc Natl Acad Sci USA 99: 7951-7955, 2002.

34. Watcharasit P, Bijur GN, Song L, Zhu J, Chen X and Jope RS: Glycogen synthase kinase-3beta (GSK3beta) binds to and promotes the actions of p53. J Biol Chem 278: 48872-48879, 2003.

35. Lang UE, Kocabayoglu P, Cheng GZ, Ghiassi-Nejad Z, Muñoz U, Vetter D, Eckstein DA, Hannivoort RA, Walsh MJ and Friedman SL: GSK3 $\beta$ phosphorylation of the KLF6 tumor suppressor promotes its transactivation of $\mathrm{p} 21$. Oncogene 32 : 4557-4564, 2013.

36. Lin J, Song T, Li C and Mao W: GSK-3 $\beta$ in DNA repair, apoptosis, and resistance of chemotherapy, radiotherapy of cancer. Biochim Biophys Acta Mol Cell Res 1867: 118659, 2020.

37. Wang L, Lin HK, Hu YC, Xie S, Yang L and Chang C: Suppression of androgen receptor-mediated transactivation and cell growth by the glycogen synthase kinase 3 beta in prostate cells. J Biol Chem 279: 32444-32452, 2004.

38. Shakoori A, Ougolkov A, Yu ZW, Zhang B, Modarressi MH, Billadeau DD, Mai M, Takahashi Y and Minamoto T: Deregulated GSK3beta activity in colorectal cancer: Its association with tumor cell survival and proliferation. Biochem Biophys Res Commun 334: 1365-1373, 2005.

39. Takahashi-Yanaga F and Sasaguri T: GSK-3beta regulates cyclin D1 expression: A new target for chemotherapy. Cell Signal 20: 581-589, 2008.

40. Verras M and Sun Z: Roles and regulation of Wnt signaling and beta-catenin in prostate cancer. Cancer Lett 237: 22-32, 2006.

41. Sharma M, Chuang WW and Sun Z: Phosphatidylinositol 3-kinase/Akt stimulates androgen pathway through GSK3beta inhibition and nuclear beta-catenin accumulation. J Biol Chem 277: 30935-30941, 2002.

42. Quintayo MA, Munro AF, Thomas J, Kunkler IH, Jack W, Kerr GR, Dixon JM, Chetty U and Bartlett JM: GSK3 $\beta$ and cyclin D1 expression predicts outcome in early breast cancer patients. Breast Cancer Res Treat 136: 161-168, 2012

43. Wang Y, Lam JB, Lam KS, Liu J, Lam MC, Hoo RL, Wu D, Cooper GJ and $\mathrm{Xu}$ A: Adiponectin modulates the glycogen synthase kinase-3beta/beta-catenin signaling pathway and attenuates mammary tumorigenesis of MDA-MB-231 cells in nude mice. Cancer Res 66: 11462-11470, 2006.

44. Baral R, Patnaik S and Das BR: Co-overexpression of p53 and c-myc proteins linked with advanced stages of betel- and tobacco-related oral squamous cell carcinomas from eastern India. Eur J Oral Sci 106: 907-913, 2010.

45. de Sousa SO, Mesquita RA, Pinto DS Jr and Gutkind S: Immunolocalization of c-Fos and c-Jun in human oral mucosa and in oral squamous cell carcinoma. J Oral Pathol Med 31: 78-81, 2002.

46. Franz M, Spiegel K, Umbreit C, Richter P, Codina-Canet C, Berndt A, Altendorf-Hofmann A, Koscielny S, Hyckel P, Kosmehl H, et al: Expression of Snail is associated with myofibroblast phenotype development in oral squamous cell carcinoma. Histochem Cell Biol 131: 651-660, 2009.

47. Iwai S, Katagiri W, Kong C, Amekawa S, Nakazawa M and Yura Y: Mutations of the APC, beta-catenin, and axin 1 genes and cytoplasmic accumulation of beta-catenin in oral squamous cell carcinoma. J Cancer Res Clin Oncol 131: 773-782, 2005.

48. Buss H, Dörrie A, Schmitz ML, Frank R, Livingstone M, Resch K and Kracht M: Phosphorylation of serine 468 by GSK-3beta negatively regulates basal p65 NF-kappaB activity. J Biol Chem 279: 49571-49574, 2004.

49. Goto H, Kawano K, Kobayashi I, Sakai H and Yanagisawa S: Expression of cyclin D1 and GSK-3beta and their predictive value of prognosis in squamous cell carcinomas of the tongue. Oral Oncol 38: 549-556, 2002.

50. Mishra A, Bharti AC, Saluja D and Das BC: Transactivation and expression patterns of Jun and Fos/AP-1 super-family proteins in human oral cancer. Int J Cancer 126: 819-829, 2010. 
51. Mishra R: Glycogen synthase kinase 3 beta: Can it be a target for oral cancer. Mol Cancer 9: 144, 2010.

52. Bauer K, Dowejko A, Bosserhoff AK, Reichert TE and Bauer RJ: P-cadherin induces an epithelial-like phenotype in oral squamous cell carcinoma by GSK-3beta-mediated Snail phosphorylation. Carcinogenesis 30: 1781-1788, 2009.

53. Kornberg LJ: Focal adhesion kinase expression in oral cancers. Head Neck 20: 634-639, 1998

54. Ko BS, Chang TC, Chen CH, Liu CC, Kuo CC, Hsu C, Shen YC, Shen TL, Golubovskaya VM, Chang CC, et al: Bortezomib suppresses focal adhesion kinase expression via interrupting nuclear factor-kappa B. Life Sci 86: 199-206, 2010.

55. Takeuchi H, Taoka R, Mmeje CO, Jinesh GG, Safe S and Kamat AM: CDODA-Me decreases specificity protein transcription factors and induces apoptosis in bladder cancer cells through induction of reactive oxygen species. Urol Oncol 34: 337.e11-e18, 2016.

56. Miller WP, Toro AL, Barber AJ and Dennis MD: REDD1 Activates a ROS-generating feedback loop in the retina of diabetic mice. Invest Ophthalmol Vis Sci 60: 2369-2379, 2019.

57. Deng S, Dai G, Chen S, Nie Z, Zhou J, Fang H and Peng H: Dexamethasone induces osteoblast apoptosis through ROS-PI3K/AKT/GSK $3 \beta$ signaling pathway. Biomed Pharmacother 110: 602-608, 2019.

58. Ziober BL, Silverman SS Jr and Kramer RH: Adhesive mechanisms regulating invasion and metastasis in oral cancer. Crit Rev Oral Biol Med 12: 499-510, 2001.

59. Erdem NF, Carlson ER, Gerard DA and Ichiki AT: Characterization of 3 oral squamous cell carcinoma cell lines with different invasion and/or metastatic potentials. J Oral Maxillofac Surg 65: 1725-1733, 2007.

60. Zhao J and Liao K: Expression of macrophage migration inhibitory factor in esophageal squamous cell carcinoma and normal esophageal tissue. Acta Acad Med Mil Tertiae 29: 740-742, 2008.

61. Liu RM, Sun DN, Jiao YL, Wang P, Zhang J, Wang M, Ma J, Sun M, Gu BL, Chen P, et al: Macrophage migration inhibitory factor promotes tumor aggressiveness of esophageal squamous cell carcinoma via activation of Akt and inactivation of GSK3 $\beta$. Cancer Lett 412: 289-296, 2018.

62. Wang H, Wang HS, Zhou BH, Li CL, Zhang F, Wang XF, Zhang G, Bu XZ, Cai SH and Du J: Epithelial-mesenchymal transition

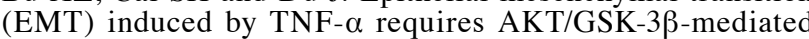
stabilization of snail in colorectal cancer. PLoS One 8: e56664, 2013.

63. Kao SH, Wang WL, Chen CY, Chang YL, Wu YY, Wang YT, Wang SP, Nesvizhskii AI, Chen YJ, Hong TM and Yang PC: GSK3 $\beta$ controls epithelial-mesenchymal transition and tumor metastasis by CHIP-mediated degradation of Slug. Oncogene 33: 3172-3182, 2014

64. Shakoori A, Mai W, Miyashita K, Yasumoto K, Takahashi Y, Ooi A, Kawakami K and Minamoto T: Inhibition of GSK-3 beta activity attenuates proliferation of human colon cancer cells in rodents. Cancer Sci 98: 1388-1393, 2007.

65. Vidri RJ and Fitzgerald TL: GSK-3: An important kinase in colon and pancreatic cancers. Biochim Biophys Acta Mol Cell Res 1867: 118626, 2020.

66. Huang W, Chang HY, Fei T, Wu H and Chen YG: GSK3 beta mediates suppression of cyclin D2 expression by tumor suppressor PTEN. Oncogene 26: 2471-2482, 2007.

67. Ban JO, Oh JH, Son SM, Won D, Song HS, Han SB, Moon DC, Kang KW, Song MJ and Hong JT: Troglitazone, a PPAR agonist, inhibits human prostate cancer cell growth through inactivation of NFKB via suppression of GSK-3 $\beta$ expression. Cancer Biol Ther 12: 288-296, 2011

68. Ban JO, Kwak DH, Oh JH, Park EJ, Cho MC, Song HS, Song MJ Han SB, Moon DC, Kang KW and Hong JT: Suppression of NF-kappaB and GSK-3beta is involved in colon cancer cell growth inhibition by the PPAR agonist troglitazone. Chem Biol Interact 188: 75-85, 2010.

69. Ghosh JC and Altieri DC: Activation of p53-dependent apoptosis by acute ablation of glycogen synthase kinase-3beta in colorectal cancer cells. Clin Cancer Res 11: 4580-4588, 2005.

70. Perse $\mathrm{M}$ and Cerar A: Morphological and molecular alterations in 1,2 dimethylhydrazine and azoxymethane induced colon carcinogenesis in rats. J Biomed Biotechnol 2011: 473964, 2011.

71. Ougolkov AV, Fernandez-Zapico ME, Bilim VN, Smyrk TC, Chari ST and Billadeau DD: Aberrant nuclear accumulation of glycogen synthase kinase-3beta in human pancreatic cancer: Association with kinase activity and tumor dedifferentiation. Clin Cancer Res 12: 5074-5081, 2006.
72. Zhou W, Wang L, Gou SM, Wang TL, Zhang M, Liu T and Wang CY: ShRNA silencing glycogen synthase kinase-3 beta inhibits tumor growth and angiogenesis in pancreatic cancer. Cancer Lett 316: 178-186, 2012

73. Cao Q, Lu X and Feng YJ: Glycogen synthase kinase-3beta positively regulates the proliferation of human ovarian cancer cells. Cell Res 16: 671-677, 2006.

74. Miyashita K, Kawakami K, Nakada M, Mai W, Shakoori A Fujisawa H, Hayashi Y, Hamada $\mathbf{J}$ and Minamoto T: Potential therapeutic effect of glycogen synthase kinase 3beta inhibition against human glioblastoma. Clin Cancer Res 15: 887-897, 2009.

75. Yang Y, Lei T, Du S, Tong R, Wang H, Yang J, Huang J, Sun M, Wang Y and Dong Z: Nuclear GSK3 $\beta$ induces DNA double-strand break repair by phosphorylating 53BP1 in glioblastoma. Int J Oncol 52: 709-720, 2018.

76. Nishimura H, Nakamura O, Yamagami Y, Mori M, Horie R, Fukuoka N and Yamamoto T: GSK-3 inhibitor inhibits cell proliferation and induces apoptosis in human osteosarcoma cells. Oncol Rep 35: 2348-2354, 2016.

77. Kerkela R, Kockeritz L, Macaulay K, Zhou J, Doble BW, Beahm C, Greytak S, Woulfe K, Trivedi CM, Woodgett JR, et al: Deletion of GSK-3beta in mice leads to hypertrophic cardiomyopathy secondary to cardiomyoblast hyperproliferation. J Clin Invest 118: 3609-3618, 2008.

78. Hoeflich KP, Luo J, Rubie EA, Tsao MS, Jin O and Woodgett JR: Requirement for glycogen synthase kinase-3beta in cell survival and NF-kappaB activation. Nature 406: 86-90, 2000.

79. McManus EJ, Sakamoto K, Armit LJ, Ronaldson L, Shpiro N, Marquez R and Alessi DR: Role that phosphorylation of GSK3 plays in insulin and Wnt signalling defined by knockin analysis. EMBO J 24: 1571-1583, 2005.

80. Wang Z, Smith KS, Murphy M, Piloto O, Somervaille TC and Cleary ML: Glycogen synthase kinase 3 in MLL leukaemia maintenance and targeted therapy. Nature 455: 1205-1209, 2008.

81. Vigneron F, Dos Santos P, Lemoine S, Bonnet M, Tariosse L, Couffinhal T, Duplaà C and Jaspard-Vinassa B: GSK-3 $\beta$ at the crossroads in the signalling of heart preconditioning: Implication of mTOR and Wnt pathways. Cardiovasc Res 90: 49-56, 2011.

82. Fu Y, Hu D, Qiu J, Xie X, Ye F and Lu WG: Overexpression of glycogen synthase kinase-3 in ovarian carcinoma cells with acquired paclitaxel resistance. Int J Gynecol Cancer 21: 439-444, 2011.

83. Grassilli E, Narloch R, Federzoni E, Ianzano L, Pisano F, Giovannoni R, Romano G, Masiero L, Leone BE, Bonin S, et al: Inhibition of GSK3B bypass drug resistance of p53-null colon carcinomas by enabling necroptosis in response to chemotherapy. Clin Cancer Res 19: 3820-3831, 2013.

84. Kawazoe H, Bilim VN, Ugolkov AV, Yuuki K, Naito S, Nagaoka A, Kato T and Tomita Y: GSK-3 inhibition in vitro and in vivo enhances antitumor effect of sorafenib in renal cell carcinoma (RCC). Biochem Biophys Res Commun 423: 490-495, 2012.

85. Cai G, Wang J, Xin X, Ke Z and Luo J: Phosphorylation of glycogen synthase kinase- 3 beta at serine 9 confers cisplatin resistance in ovarian cancer cells. Int J Oncol 31: 657-662, 2007.

86. Beurel E, Kornprobst M, Blivet-Van Eggelpoël MJ, Cadoret A, Capeau J and Desbois-Mouthon C: GSK-3beta reactivation with LY294002 sensitizes hepatoma cells to chemotherapy-induced apoptosis. Int J Oncol 27: 215-222, 2005.

87. Alao JP, Stavropoulou AV, Lam WF and Coombes RC: Role of glycogen synthase kinase 3 beta (GSK3beta) in mediating the cytotoxic effects of the histone deacetylase inhibitor trichostatin A (TSA) in MCF-7 breast cancer cells. Mol Cancer 5: 40, 2006.

88. Pyko IV, Nakada M, Sabit H, Teng L, Furuyama N, Hayashi Y, Kawakami K, Minamoto T, Fedulau AS and Hamada J: Glycogen synthase kinase $3 \beta$ inhibition sensitizes human glioblastoma cells to temozolomide by affecting O6-methylguanine DNA methyltransferase promoter methylation via c-Myc signaling. Carcinogenesis 34: 2206-2217, 2013.

89. Shimasaki T, Ishigaki Y, Nakamura Y, Takata T, Nakaya N, Nakajima H, Sato I, Zhao X, Kitano A, Kawakami K, et al: Glycogen synthase kinase $3 \beta$ inhibition sensitizes pancreatic cancer cells to gemcitabine. J Gastroenterol 47: 321-333, 2012.

90. Kitano A, Shimasaki T, Chikano Y, Nakada M, Hirose M, Higashi T, Ishigaki Y, Endo Y, Takino T, Sato H, et al: Aberrant glycogen synthase kinase $3 \beta$ is involved in pancreatic cancer cell invasion and resistance to therapy. PLoS One 8: e55289, 2013.

91. Maqbool M and Hoda N: GSK3 inhibitors in the therapeutic development of diabetes, cancer and neurodegeneration: Past, present and future. Curr Pharm Des 23: 4332-4350, 2017. 
92. Bowden CL: Efficacy of lithium in mania and maintenance therapy of bipolar disorder. J Clin Psychiatry 61 (Suppl 9): S35-S40, 2000.

93. Del Grande C, Muti M, Musetti L, Pergentini I, Corsi M, Turri M, Soldani I, Corsini GU and Dell'Osso L: Long-term treatment of bipolar disorder: How should we use lithium salts? Riv Psichiatr 47: 515-526, 2012 (In Italian).

94. Clément-Lacroix P, Ai M, Morvan F, Roman-Roman S, Vayssière B, Belleville C, Estrera $\mathrm{K}$, Warman ML, Baron R and Rawadi G: Lrp5-independent activation of Wnt signaling by lithium chloride increases bone formation and bone mass in mice. Proc Natl Acad Sci USA 102: 17406-17411, 2005.

95. Stump RJ, Lovicu FJ, Ang SL, Pandey SK and McAvoy JW: Lithium stabilizes the polarized lens epithelial phenotype and inhibits proliferation, migration, and epithelial mesenchymal transition. J Pathol 210: 249-257, 2010.

96. Sun A, Shanmugam I, Song J, Terranova PF, Thrasher JB and Li B: Lithium suppresses cell proliferation by interrupting E2F-DNA interaction and subsequently reducing S-phase gene expression in prostate cancer. Prostate 67: 976-988, 2007.

97. Song L, Zhou T and Jope RS: Lithium facilitates apoptotic signaling induced by activation of the Fas death domain-containing receptor. BMC Neurosci 5: 20, 2004.

98. Karlovic D, Jakopec S, Dubravcic K, Batinic D, Buljan D and Osmak M: Lithium increases expression of p21 WAF/Cip1 and survivin in human glioblastoma cells. Cell Biol Toxicol 23: 83-90, 2007

99. Neel BD, Lopez J, Chabadel A and Gillet G: Lithium suppresses motility and invasivity of v-src-transformed cells by glutathione-dependent activation of phosphotyrosine phosphatases. Oncogene 28: 3246-3260, 2009.

100. Hilliard T, Muehlbauer A, Gaisina I, Gaisin A, Gallier F, Kozikowski A and Burdette J: Novel glycogen synthase kinase 3 beta inhibitors induce apoptosis in ovarian cancer. Biol Reprod 83 (Suppl 1): S691, 2010.

101. Rinnab L, Schütz SV, Diesch J, Schmid E, Küfer R, Hautmann RE, Spindler KD and Cronauer MV: Inhibition of glycogen synthase kinase-3 in androgen-responsive prostate cancer cell lines: Are GSK inhibitors therapeutically useful? Neoplasia 10: 624-634, 2008.

102. Schütz SV, Schrader AJ, Zengerling F, Genze F, Cronauer MV and Schrader M: Inhibition of glycogen synthase kinase- $3 \beta$ counteracts ligand-independent activity of the androgen receptor in castration resistant prostate cancer. PLoS One 6: e25341, 2011.

103. Marchand B, Tremblay I, Cagnol S and Boucher MJ: Inhibition of glycogen synthase kinase-3 activity triggers an apoptotic response in pancreatic cancer cells through JNK-dependent mechanisms. Carcinogenesis 33: 529-537, 2012.

104. Coghlan MP, Culbert AA, Cross DA, Corcoran SL, Yates JW, Pearce NJ, Rausch OL, Murphy GJ, Carter PS, Roxbee Cox L, et al: Selective small molecule inhibitors of glycogen synthase kinase-3 modulate glycogen metabolism and gene transcription. Chem Biol 7: 793-803, 2000.

105. Beurel E, Blivet-Van Eggelpoel MJ, Kornprobst M, Moritz S, Delelo R, Paye F, Housset C and Desbois-Mouthon C: Glycogen synthase kinase-3 inhibitors augment TRAIL-induced apoptotic death in human hepatoma cells. Biochem Pharmacol 77: 54-65, 2009

106. Piazza F, Manni S, Tubi LQ, Montini B, Pavan L, Colpo A, Gnoato M, Cabrelle A, Adami F, Zambello R, et al: Glycogen Synthase Kinase-3 regulates multiple myeloma cell growth and bortezomib-induced cell death. BMC Cancer 10: 526 , 2010.

107. Dickey A, Schleicher S, Leahy K, Hu R, Hallahan D and Thotala DK: GSK-3 $\beta$ inhibition promotes cell death, apoptosis, and in vivo tumor grow th delay in neuroblastoma Neuro-2A cell line. J Neurooncol 104: 145-153, 2011.

108. Zhu Q, Yang J, Han S, Liu J, Holzbeierlein J, Thrasher JB and $\mathrm{Li}$ B: Suppression of glycogen synthase kinase 3 activity reduces tumor growth of prostate cancer in vivo. Prostate 71: 835-845, 2011.

109. Yan P, Tang H, Chen X, Ji S, Jin W, Zhang J, Shen J, Deng H, Zhao X, Shen Q and Huang H: Tamoxifen attenuates dialysate-induced peritoneal fibrosis by inhibiting GSK-3 $\beta / \beta$-catenin axis activation. Biosci Rep 38: BSR20180240, 2018.

110. Tang YY, Sheng SY, Lu CG, Zhang YQ, Zou JY, Lei YY, Gu Y and Hong $\mathrm{H}$ : Effects of glycogen synthase kinase-3 $\beta$ inhibitor TWS119 on proliferation and cytokine production of TILs from human lung cancer. J Immunother 41: 319-328, 2018.
111. Guzmán EA, Johnson JD, Linley PA, Gunasekera SE and Wright AE: A novel activity from an old compound: Manzamine A reduces the metastatic potential of AsPC-1 pancreatic cancer cells and sensitizes them to TRAIL-induced apoptosis. Invest New Drugs 29: 777-785, 2011.

112. Mamaghani S, Patel S and Hedley DW: Glycogen synthase kinase-3 inhibition disrupts nuclear factor-kappaB activity in pancreatic cancer, but fails to sensitize to gemcitabine chemotherapy. BMC Cancer 9: 132, 2009.

113. Gaisina IN, Gallier F, Ougolkov AV, Kim KH, Kurome T, Guo S, Holzle D, Luchini DN, Blond SY, Billadeau DD and Kozikowski AP: From a natural product lead to the identification of potent and selective benzofuran-3-yl-(indol-3-yl) maleimides as glycogen synthase kinase 3beta inhibitors that suppress proliferation and survival of pancreatic cancer cells. J Med Chem 52: 1853-1863, 2009.

114. Kuroki H, Anraku T, Kazama A, Bilim V, Tasaki M, Schmitt D, Mazar AP, Giles FJ, Ugolkov A and Tomita Y: 9-ING-41, a small molecule inhibitor of GSK-3beta, potentiates the effects of anticancer therapeutics in bladder cancer. Sci Rep 9: 19977, 2019.

115. Anraku T, Kuroki H, Kazama A, Bilim V, Tasaki M, Schmitt D, Mazar A, Giles FJ, Ugolkov A and Tomita Y: Clinically relevant GSK3 $\beta$ inhibitor 9-ING-41 is active as a single agent and in combination with other antitumor therapies in human renal cancer. Int J Mol Med 45: 315-323, 2020.

116. Ugolkov AV, Bondarenko GI, Dubrovskyi O, Berbegall AP, Navarro S, Noguera R, O'Halloran TV, Hendrix MJ, Giles FJ and Mazar AP: 9-ING-41, a small-molecule glycogen synthase kinase-3 inhibitor, is active in neuroblastoma. Anticancer Drugs 29: 717-724, 2018.

117. Karmali R, Chukkapalli V, Gordon LI, Borgia JA, Ugolkov A, Mazar AP and Giles FJ: GSK-3 $\beta$ inhibitor, 9-ING-41, reduces cell viability and halts proliferation of B-cell lymphoma cell lines as a single agent and in combination with novel agents. Oncotarget 8: 114924-114934, 2017.

118. Ugolkov A, Gaisina I, Zhang JS, Billadeau DD, White K, Kozikowski A, Jain S, Cristofanilli M, Giles F, O'Halloran T, et al: GSK-3 inhibition overcomes chemoresistance in human breast cancer. Cancer Lett 380: 384-392, 2016.

119. Ugolkov A, Qiang W, Bondarenko G, Procissi D, Gaisina I, James CD, Chandler J, Kozikowski A, Gunosewoyo H, O'Halloran T, et al: Combination treatment with the GSK-3 Inhibitor 9-ING-41 and CCNU cures orthotopic chemoresistant glioblastoma in patient-derived xenograft models. Transl Oncol 10: 669-678, 2017

120. Hilliard TS, Gaisina IN, Muehlbauer AG, Gaisin AM, Gallier F and Burdette JE: Glycogen synthase kinase $3 \beta$ inhibitors induce apoptosis in ovarian cancer cells and inhibit in-vivo tumor growth. Anticancer Drugs 22: 978-985, 2011.

121. Jeffers A, Qin W, Owens S, Koenig KB, Komatsu S, Giles FJ, Schmitt DM, Idell S and Tucker TA: Glycogen synthase kinase-3 $\beta$ inhibition with 9-ING-41 attenuates the progression of pulmonary fibrosis. Sci Rep 9: 18925, 2019.

122. Gotschel F, Kern C, Lang S, Sparna T, Markmann C, Schwager J, McNelly S, von Weizsäcker F, Laufer S, Hecht A and Merfort I: Inhibition of GSK3 differentially modulates NF-kappaB, CREB, AP-1 and beta-catenin signaling in hepatocytes, but fails to promote TNF-alpha-induced apoptosis. Exp Cell Res 314: 1351-1366, 2008.

123. Cheng Y, Pardo M, Armini RS, Martinez A, Mouhsine H, Zagury JF, Jope RS and Beurel E: Stress-induced neuroinflammation is mediated by GSK3-dependent TLR4 signaling that promotes susceptibility to depression-like behavior. Brain Behav Immun 53: 207-222, 2016.

124. Hoffmeister L, Diekmann M, Brand K and Huber R: GSK3: A kinase balancing promotion and resolution of inflammation. Cells 9: 820, 2020.

125. Teng L, Meng Q, Lu J, Xie J, Wang Z, Liu Y and Wang D: Liquiritin modulates ERK and AKT/GSK-3 $\beta$-dependent pathways to protect against glutamate-induced cell damage in differentiated PC12 cells. Mol Med Rep 10: 818-824, 2014.

126. Gerhardt D, Bertola G, Dietrich F, Figueiró F, Zanotto-Filho A, Moreira Fonseca JC, Morrone FB, Barrios CH, Battastini AM and Salbego CG: Boldine induces cell cycle arrest and apoptosis in T24 human bladder cancer cell line via regulation of ERK, AKT, and GSK-33. Urol Oncol 32: 36.e1-e9, 2014.

127. Kwon HJ, Kwon SJ, Lee H, Park HR, Choi GE, Kang SW, Kwon SW, Kim N, Lee SY, Ryu S, et al: NK cell function triggered by multiple activating receptors is negatively regulated by glycogen synthase kinase-3 $\beta$. Cell Signal 27: 1731-1741, 2015. 
128. Fionda C, Soriani A, Zingoni A, Santoni A and Cippitelli M NKG2D and DNAM-1 ligands: Molecular targets for NK cell-mediated immunotherapeutic intervention in multiple myeloma. Biomed Res Int 2015: 178698, 2015.

129. Fionda C, Malgarini G, Soriani A, Zingoni A, Cecere F, Iannitto ML, Ricciardi MR, Federico V, Petrucci MT, Santoni A and Cippitelli M: Inhibition of glycogen synthase kinase-3 increases NKG2D ligand MICA expression and sensitivity to NK cell-mediated cytotoxicity in multiple myeloma cells: Role of STAT3. J Immunol 190: 6662-6672, 2013.

130. Parameswaran R, Ramakrishnan P, Moreton SA, Xia Z, Hou Y, Lee DA, Gupta K, deLima M, Beck RC and Wald DN: Repression of GSK3 restores NK cell cytotoxicity in AML patients. Nat Commun 7: 11154, 2016.

131. Cichocki F, Valamehr B, Bjordahl R, Zhang B, Rezner B, Rogers P, Gaidarova S, Moreno S, Tuininga K, Dougherty P, et al: GSK3 inhibition drives maturation of NK cells and enhances their antitumor activity. Cancer Res 77: 5664-5675, 2017.

132. Ohteki T, Parsons M, Zakarian A, Jones RG, Nguyen LT, Woodgett JR and Ohashi PS: Negative regulation of T cell proliferation and interleukin 2 production by the serine threonine kinase GSK-3. J Exp Med 192: 99-104, 2000.

133. Taylor A and Rudd CE: Glycogen synthase kinase 3 inactivation compensates for the lack of $\mathrm{CD} 28$ in the priming of $\mathrm{CD}^{+}$ cytotoxic T-cells: Implications for anti-PD-1 immunotherapy. Front Immunol 8: 1653, 2017.

134. Taylor A, Harker JA, Chanthong K, Stevenson PG, Zuniga EI and Rudd CE: Glycogen synthase kinase 3 inactivation drives T-bet-mediated downregulation of Co-receptor PD-1 to enhance CD8(+) cytolytic T cell responses. Immunity 44: 274-286, 2016

135. Taylor A, Rothstein D and Rudd CE: Small-molecule inhibition of PD-1 transcription is an effective alternative to antibody blockade in cancer therapy. Cancer Res 78: 706-717, 2018.

136. Rudd CE, Chanthong K and Taylor A: Small molecule inhibition of GSK-3 specifically inhibits the transcription of inhibitory Co-receptor LAG-3 for enhanced anti-tumor immunity. Cell Rep 30: 2075-2082.e4, 2020.

137. Zhang JY, Zhao YL, Lv YP, Cheng P, Chen W, Duan M, Teng YS, Wang TT, Peng LS, Mao FY, et al: Modulation of $\mathrm{CD}^{+}$memory stem $\mathrm{T}$ cell activity and glycogen synthase kinase $3 \beta$ inhibition enhances anti-tumoral immunity in gastric cancer. Oncoimmunology 7: e1412900, 2018.
138. Xia Y, Zhuo H, Lu Y, Deng L, Jiang R, Zhang L, Zhu Q, Pu L, Wang $X$ and Lu L: Glycogen synthase kinase $3 \beta$ inhibition promotes human iTreg differentiation and suppressive function. Immunol Res 62: 60-70, 2015.

139. Sengupta S, Katz SC, Sengupta S and Sampath P: Glycogen synthase kinase 3 inhibition lowers PD-1 expression, promotes long-term survival and memory generation in antigen-specific CAR-T cells. Cancer Lett 433: 131-139, 2018.

140. Takeuchi H, Tanaka M, Tanaka A, Tsunemi A and Yamamoto H: Predominance of M2-polarized macrophages in bladder cancer affects angiogenesis, tumor grade and invasiveness. Oncol Lett 11: 3403-3408, 2016.

141. Wang G, Shi Y, Jiang X, Leak RK, Hu X, Wu Y, Pu H, Li WW, Tang $\mathrm{B}$, Wang Y, et al: HDAC inhibition prevents white matter injury by modulating microglia/macrophage polarization through the GSK3 $3 /$ PTEN/Akt axis. Proc Natl Acad Sci USA 112: 2853-2858, 2015

142. Mazor M, Kawano Y,Zhu H, Waxman J and Kypta RM: Inhibition of glycogen synthase kinase-3 represses androgen receptor activity and prostate cancer cell growth. Oncogene 23: 7882-7892, 2004.

143. Goc A, Al-Husein B, Katsanevas K, Steinbach A, Lou U, Sabbineni H, DeRemer DL and Somanath PR: Targeting Src-mediated Tyr216 phosphorylation and activation of GSK-3 in prostate cancer cells inhibit prostate cancer progression in vitro and in vivo. Oncotarget 5: 775-787, 2014.

144. Yu XJ, Han QB, Wen ZS, Ma L, Gao J and Zhou GB: Gambogenic acid induces G1 arrest via GSK3 $\beta$-dependent cyclin D1 degradation and triggers autophagy in lung cancer cells. Cancer Lett 322: 185-194, 2012.

145. Kunnimalaiyaan S, Gamblin TC and Kunnimalaiyaan M: Glycogen synthase kinase-3 inhibitor AR-A014418 suppresses pancreatic cancer cell growth via inhibition of GSK-3-mediated Notch1 expression. HPB (Oxford) 17: 770-776, 2015.

This work is licensed under a Creative Commons Attribution-NonCommercial-NoDerivatives 4.0 International (CC BY-NC-ND 4.0) License. 